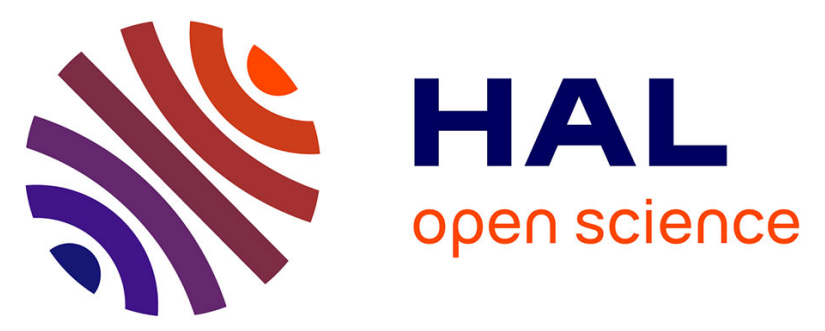

\title{
Short Communication: Extremely Severe CD4 Lymphopenia During HIV-1 Primary Infection
}

Benjamin Bonnet, Laurent Blum, Charlotte Charpentier, Pascale Martres, Paul-Gydeon Ritvo, Brigitte Autran, Amelie Guihot

\section{- To cite this version:}

Benjamin Bonnet, Laurent Blum, Charlotte Charpentier, Pascale Martres, Paul-Gydeon Ritvo, et al. Short Communication: Extremely Severe CD4 Lymphopenia During HIV-1 Primary Infection. AIDS Research and Human Retroviruses, 2019, 35 (10), pp.930-933. 10.1089/AID.2019.0065 . hal02433578

\section{HAL Id: hal-02433578 \\ https://hal.sorbonne-universite.fr/hal-02433578}

Submitted on 9 Jan 2020

HAL is a multi-disciplinary open access archive for the deposit and dissemination of scientific research documents, whether they are published or not. The documents may come from teaching and research institutions in France or abroad, or from public or private research centers.
L'archive ouverte pluridisciplinaire HAL, est destinée au dépôt et à la diffusion de documents scientifiques de niveau recherche, publiés ou non, émanant des établissements d'enseignement et de recherche français ou étrangers, des laboratoires publics ou privés. 


\section{Extremely severe CD4 lymphopenia during HIV-1 primary infection}

Benjamin Bonnet ${ }^{1}$, Laurent Blum ${ }^{2}$, Charlotte Charpentier ${ }^{3}$, Pascale Martres ${ }^{4}$, Paul-Gydeon Ritvo ${ }^{5}$, Brigitte Autran $^{1,6,7}$, Amélie Guihot ${ }^{1,6,7}$

${ }^{1}$ AP-HP, Hôpital Pitié-Salpêtrière, Département d'Immunologie, Paris, F-75013, France

${ }^{2}$ Centre Hospitalier René Dubos, Service de médecine, Pontoise, F-95300, France

${ }^{3}$ IAME, UMR 1137, INSERM, Université Paris Diderot, Sorbonne Paris Cité, AP-HP, Laboratoire de Virologie, Hôpital Bichat, AP-HP, Paris, France;

${ }^{4}$ Centre hospitalier René Dubos, laboratoire de microbiologie, Pontoise, F-95300, France

${ }^{5}$ INSERM, U959, F-75013, Paris, France

${ }^{6}$ Sorbonne Universités, UPMC Univ Paris 06, Centre d'Immunologie et des Maladies Infectieuses (CIMIParis), F-75013, Paris, France

${ }^{7}$ INSERM, U1135, CIMI-Paris, F-75013, Paris, France

Keywords: HIV, CD4, immunosuppression, Antibody, primary HIV infection, combined antiretroviral therapy, T cell

RUNNING TITLE: Severe immunosuppression during primary HIV infection.

Conflicts of Interest and Source of Funding: None to declare

Correspondence to : Dr Amélie Guihot, Hôpital Pitié-Salpêtrière, Département d'Immunologie, 83 bd de l'hôpital, 75013 Paris, France

Phone number : (33) 142177930 E-mail : amelie.guihot@aphp.fr, 


\section{Abstract (47 words)}

We report the case of a patient with a very profound CD4-T cell lymphopenia below 20 cells $/ \mathrm{mm}^{3}$ in the context of a primary HIV-1 infection, associated with both delayed HIV-specific antibody and CD8-T cell responses. A long-term Immune reconstitution was observed after immediate initiation of antiretroviral therapy. 


\section{2 / 1200 w}

While the possible occurrence of opportunistic infections during HIV primary infection is well known, the CD4 T cell count does not usually drop below 40 CD4/mm3 (range 40-1542/mm3 (1). The CD4 cell count was described below $20 / \mathrm{mm} 3$ in only two cases, one with P. jiroveci co-infection (2) and one in a hemophagocytic syndrome context (3). After primary infection, the serology is usually positive except very early -about 20 days- after infection (4) and HIV-specific CD4 T cell responses are normally rapidly detected after early onset of combined antiretroviral therapy (cART) (5).

Here we report a case of an HIV primary infection together with an exceptionally profound CD4 T cell lymphopenia and without severe documented co-infection. A delay in both seroconversion and $\mathrm{T}$ cell responses to HIV was observed, together with a well-documented successful immune restoration.

A 52-year-old Nigerian woman living in France was hospitalized for alteration of the general status. She had a heterosexual behavior at risk for HIV infection 3 months before in Nigeria. Fifteen days after arrival in France, she suffered from asthenia, oscillating fever, weight loss $(-9 \mathrm{~kg})$, microbiologically negative necrotic ulcer of the right tonsil and oral candidiasis. When hospitalized, ELISA HIV serology suggested a positivity related to P24 antigen positivity alone, while the Western Blot (WB) showed an incomplete profile with positivity of the P24 and P55 bands (Figure 1A) $(6,7)$. The RT-PCR analysis confirmed HIV infection with a high viral load $(787,000$ copies/mL, Figure $1 \mathrm{~A}, \mathrm{~B})$. HIV-1 strain was subtyped as CRF06_cpx. Genotypic resistance test showed a wild-type virus for reverse transcriptase and protease regions and a E157Q polymorphism in the integrase, with a non-CCR5 tropic strain. No other co-infection was found. The syphilis serology was negative and the virological analysis of the ulcer of the right tonsil was negative for EBV and CMV. The immunophenotyping revealed a major CD4 T cell defect $(12 / \mu \mathrm{L})$ together with a low CD8 T cell $(216 / \mu \mathrm{L})$ and a low B cell $(52 / \mu \mathrm{L})$ counts, contrasting with a normal NK cell count $(168 / \mu \mathrm{L})$ (Figure 1A, B). The patient was treated within three days with fluconazole and tenofovir, emtricitabine and ritonavir boosted darunavir. 
Clinical improvement was rapidly observed. Surprisingly, HIV 1 \& 2 serology and WB analysis performed 15 days after CART initiation showed negative results and an incomplete profile with a unique positivity at the P24 band and an equivocal P55 band (Figure 1A). At month 8, both ELISA and WB serologies were fully positive. The HIV plasma load reached undetectability at month 13 of treatment (Figure 1A, B). A slowly progressive CD4-T cell reconstitution was observed from $12 / \mu \mathrm{L}$ at D0 to $134 / \mu \mathrm{L}$ at 2 months, $245 / \mu \mathrm{L}$ at 8 months, $299 / \mu \mathrm{L}$ at month 25 and 527/ $\mu \mathrm{L}$ at 39 month (Figure $1 \mathrm{~B}, \mathrm{C}$ ). Simultaneously, the total lymphocyte cell count increased from $400 / \mathrm{mm} 3$ at D0 to $1264 / \mathrm{mm} 3$ at M25. The initial collapse of naive CD45RA+CCR7+CD4+ T cells (Figure 1D) was followed by a subsequent increase at M25 post cART (Figure 1D). The in vitro T cell proliferation assays showed a lack of memory T cell responses to all recall antigens tested except for Candidin at M2 post-cART (Figure 1E). Five months after cART initiation, memory $\mathrm{T}$ cell responses to Cytomegalovirus (CMV), and Herpes Simplex Virus (HSV) were restored, though without responses to the HIV-p24 antigen (Figure 1E). The CD8 T cell count also progressively increased (Figure 1B). Activated CD8 T cells assessed by HLA-DR+CD38+ co-expression increased progressively up to M2 then gradually decreased reaching normal values at M19 (Figure 1E). The HIVspecific effector-memory CD8 T cells analyzed ex-vivo by using an IFN- $\gamma$ ELIspot assay against 15-mer overlapping peptides covering p24, p17, Nef and RT showed negative responses during the first 2 months post-CART (all responses $<50 \mathrm{SFC} / 10^{6} \mathrm{PBMC}$ ), became weakly positive at $\mathrm{M} 4$, probably related to partially controlled HIV replication (87 and 153 SFC/106 PBMC against P24 and Nef, respectively) and then negative again at M8 (Figure $1 \mathrm{~A})$.

Here we report a case of a primary HIV infection with an unusual extremely severe immune suppression and CD4 T cell lymphopenia occurring in an adult with no pre-existing evidences of immune suppression. The CD4 count was not linked to the result of documented co-infection but could have been linked to the loss of activated cell or due to some predisposing genetic state or condition that might accentuate CD4 loss in acute HIV infection $(1,2,8)$. In this case, several characteristics were unusual in addition to this 
major CD4 lymphopenia: first HIV tropism has been determined as non-CCR5 based on V3 loop sequence which is uncommon during a primary HIV infection but has been reported in 10 to $15 \%$ of cases (9). Noteworthy, the virus tropism was probably a CXCR4-tropic HIV, which is known to induced more profound CD4 lymphopenia (10). Second a very delayed HIV-specific humoral response detected only at Month 8 after cART (4); third the T cell anergy assessed by the extremely poor memory CD4 T cell response to HIV-p24 (5) and the negativity of the anti-HIV ELISpot assay (11). The immune reconstitution with cART was also partial though following some classical findings: first, a rapid and strong increase in CD4 and CD8 T cell counts, corresponding to the desequestration from lymph nodes, was however followed by a much lower pace of CD4 cell count continuous increase (12). Those observations can be explained by (a) thymic production of naïve cells as shown by the increase of CCR7+CD45RA+CD4+ cells in blood (Figure 1D)(13), (b) by stopping the conversion of naïve CD4 T cells to memory T cell after treatment and (c) by the decrease of the Activation-Induced Cell Death (AICD) attested by decreased activation markers (HLA-DR, CD25) and apoptosis marker (CD95) on CD4+ cells (Figure 1D) thanks to the viral load negativity. Also, the transient detectability of HIV-specific CD8 T cells that disappeared later-on with viral control has already been described before (14).

Regarding the HIV-specific antibodies responses, the unexpected negativity of the combined ELISA and WB 2 weeks after cART initiation can potentially due to the profound immunosuppression. Nevertheless, the delay of the WB positivity does not exclude that the patient was diagnosed during the chronic phase of the HIV infection. Unfortunately, no blood sample was done before the diagnosis. However, the WB analysis showed a typical profile of primary infection with the low positivity of the HIV-1 p24 and p55 bands on WB (incomplete profile) $(6,7)$, which was highly suggestive of acute infection in this particular clinical context. In the literature, negative results of HIV-1 antibody tests for patients who were tested positive for p24 antigenemia and/or HIV-1 nucleic acid amplification have been reported during rapid and severe disease course (15). 
Noteworthy, in our patient, the possibility of an underlying common variable immunodeficiency (CVID) was ruled out with normal subsequent gammaglobulin levels (16) although HIV infection can normalize IgG levels in CVID patients (17). No genotyping evidence for an underlying primary immunodeficiency was found. While it is well known that the rapid negativation the viral load with extremely early therapy may result in a major delay in the positivation of the HIV serology (4), the lack of HIV viral load determination between D0 and M5 prevents us to extrapolate data about a rapid virological control or not. However, the patient is still in the standard curve for HIV viral load decrease because the initial VL has raised to 5.9 log so the decrease of the VL corresponds to what is expected in terms of delay: the objective is $<50$ copies/mL at M6 with an exception for the initial VLs> 5 log for which the time of attaining undetectability can be longer according to the French guidelines (18).

So far, our hypothesis is that the initial extremely severe depletion in CD4 T cells had severely altered the T helper responses to the HIV-specific CD8 T cells which might have altered cytotoxicity on HIV-infected cells and delayed undetectability of the HIV viral load. Clinicians should be aware that such severe immunosuppression can be observed in the context of primary HIV infection with alteration of the general status but without severe co-infection, and can be associated with a delay in the seroconversion to HIV. This immunosuppression can be only partially corrected with rapid onset of antiretroviral therapy.

\section{Acknowledgements}

The authors thank Christophe Parizot for help with flow cytometry. 


\section{References}

1. Ghosn J, Deveau C, Chaix M-L, Goujard C, Galimand J, Zitoun Y, et al. Despite being highly diverse, immunovirological status strongly correlates with clinical symptoms during primary HIV-1 infection: a cross-sectional study based on 674 patients enrolled in the ANRS CO 06 PRIMO cohort. J Antimicrob Chemother. 2010 Apr;65(4):741-8.

2. Socías ME, Sued O, Laufer N, Lázaro ME, Mingrone H, Pryluka D, et al. Acute retroviral syndrome and high baseline viral load are predictors of rapid HIV progression among untreated Argentinean seroconverters. J Int AIDS Soc. 2011 Aug 10;14:40.

3. Ferraz RV, Carvalho AC, Araújo F, Koch C, Abreu C, Sarmento A. Acute HIV infection presenting as hemophagocytic syndrome with an unusual serological and virological response to ART. BMC Infect Dis [Internet]. 2016 Dec [cited 2019 Jan 3];16(1). Available from: http://bmcinfectdis.biomedcentral.com/articles/10.1186/s12879-016-1945-9

4. de Souza MS, Pinyakorn S, Akapirat S, Pattanachaiwit S, Fletcher JLK, Chomchey N, et al. Initiation of Antiretroviral Therapy During Acute HIV-1 Infection Leads to a High Rate of Nonreactive HIV Serology. Clin Infect Dis. 2016 Aug 15;63(4):555-61.

5. Rosenberg ES, Altfeld M, Poon SH, Phillips MN, Wilkes BM, Eldridge RL, et al. Immune control of HIV-1 after early treatment of acute infection. Nature. 2000;407:4.

6. Zolla-Pazner S, Gorny MK, Honnen WJ, Pinter A. Reinterpretation of human immunodeficiency virus western blot patterns. N Engl J Med. 1989 May 11;320(19):1280-1.

7. Lange JM, Paul DA, Huisman HG, de Wolf F, van den Berg H, Coutinho RA, et al. Persistent HIV antigenaemia and decline of HIV core antibodies associated with transition to AIDS. Br Med J Clin Res Ed. 1986 Dec 6;293(6560):1459-62.

8. Ungprasert P, Permpalung N, Srivali N, Bischof EF, Edmonds LC. Pneumocystis pneumonia during primary HIV infection: a case report and review of the literature. J Infect Chemother. 2013;19(5):990-1.

9. Frange P, Chaix M-L, Raymond S, Galimand J, Deveau C, Meyer L, et al. Low Frequency of CXCR4Using Viruses in Patients at the Time of Primary Non-Subtype-B HIV-1 Infection?. J CLIN MICROBIOL. 2010;48:5.

10. Schramm B, Penn ML, Speck RF, Chan SY, De Clercq E, Schols D, et al. Viral Entry through CXCR4 Is a Pathogenic Factor and Therapeutic Target in Human Immunodeficiency Virus Type 1 Disease. J Virol. 2000 Jan;74(1):184-92.

11. Streeck H, Lu R, Beckwith N, Milazzo M, Liu M, Routy J-P, et al. Emergence of Individual HIV-Specific CD8 T Cell Responses during Primary HIV-1 Infection Can Determine Long-Term Disease Outcome. J Virol. 2014 Nov;88(21):12793-801.

12. Guihot A, Tubiana R, Breton G, Marcellin A, Samiri A, Assoumou L, et al. Immune and virological benefits of 10 years of permanent viral control with antiretroviral therapy. AIDS. 2010;614-7. 
13. Autran B, Carcelain G, Li TS, Blanc C, Mathez D, Tubiana R, et al. Positive effects of combined antiretroviral therapy on CD4+ T cell homeostasis and function in advanced HIV disease. Science. $1997 \mathrm{Jul} 4 ; 277(5322): 112-6$.

14. Bouscarat F, Levacher-Clergeot M, Dazza MC, Strauss KW, Girard PM, Ruggeri C, et al. Correlation of CD8 lymphocyte activation with cellular viremia and plasma HIV RNA levels in asymptomatic patients infected by human immunodeficiency virus type 1. AIDS Res Hum Retroviruses. 1996 Jan 1;12(1):17-24.

15. Montagnier L, Brenner C, Chamaret S, Guétard D, Blanchard A, de Saint Martin J, et al. Human immunodeficiency virus infection and AIDS in a person with negative serology. J Infect Dis. 1997 Apr;175(4):955-9.

16. Padiglione A, Aleksic E, French M, Arnott A, Wilson KM, Tippett E, et al. Extremely prolonged HIV seroconversion associated with an MHC haplotype carrying disease susceptibility genes for antibody deficiency disorders. Clin Immunol Orlando Fla. 2010 Nov;137(2):199-208.

17. Balugo-López V, Hernández García de la Barrera E, Sastre J. Resolution of Common Variable Immunodeficiency After HIV Infection. J Investig Allergol Clin Immunol. 2016;26(5):333-4.

18. Blanc A, Bonnet F, Brun-Vezinet F, Costagliola D, Dabis F, Delobel P, et al. Groupe des experts « Prise en charge médicale des personnes infectées par le VIH ». 2018;57. 